\title{
Den tvetydige omsorgen
}

Haave P.

\section{Ambisjon og handling}

Sanderud sykehus og norsk psykiatri i historisk perspektiv. 549 s, tab, ill. Oslo: Unipub, 2008.

Pris NOK 479

ISBN 978-82-7477-378-3

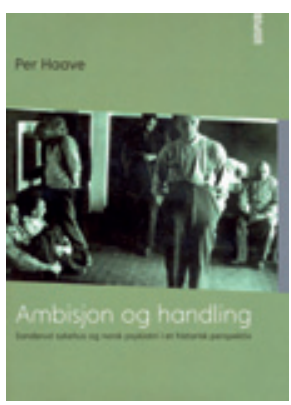

«Johannes» ble innlagt ved Sanderud sykehus i midten av 1920-årene og tilbrakte til å begynne med mye tid $\mathrm{i}$ isolat og i belter på vaktsalen pga. «ugrei oppførsel». Stadig oftere kom han i krangel både med medpasienter og

personell. I 1938 fikk han en såkalt sovekur, som betydde at han ble lagt i dyp sedasjon i ti dager. Men fremdeles var det mye å utsette på oppførselen. Han var «like forferdelig til å skrike og bråke, like negativistisk og vanskelig å stelle, like skjennende og sint, urenslig og sønderrivende» som før. Man bestemte derfor å forsøke cardiazol (pentametylenetetrazol), også omtalt som krampeterapi. Midlet forårsaket toniskkloniske anfall - tanken var at krampeanfallene skulle helbrede schizofrenien. Totalt fikk han 16 «sjokk», men etter behandlingens slutt var Johannes praktisk talt uforandret.

Han fikk siden trukket tennene, i håp om at fjerning av de «fokale infeksjoner» i munnhulen skulle hjelpe. I 1940 forsøkte man så insulinsjokk. Behandlingen var omfattende, i alt 149 dager, med 27 «hviledager» innimellom. Totalt fikk han 136 halvsjokk, på til sammen 112 timer, og 117 «sjokk», som i alt varte 69 timer. Ti epileptiske anfall fikk han under kuren, og tre av dagene falt han bevisstløs om etter dagens behandling. Året etter ble han kastrert, uten at det førte til noen åpenbar endring. Det meste av tiden tilbrakte han $\mathrm{i}$ isolat. Av og til fikk han elektrosjokk, også det uten synderlig virkning.

Etter alle disse feilslåtte behandlingsforsøkene var Johannes en opplagt kandidat da de startet med lobotomi ved Sanderud sykehus, og han ble valgt ut som en av de første. Det inntraff imidlertid komplikasjoner i form av blødning, og en uke etter operasjonen var han død. Han var en av fire som døde på Sanderud som følge av lobotomi.

Denne sterke historien står å lese i historiker Per Haaves nye bok om Sanderud sykehus' historie. Haave har tidligere skrevet godt om mørke kapitler i vår historie, som f.eks. sterilisering av tatere (1). Sanderud sykehus må gis honnør for å ha gitt oppdraget å skrive jubileumsboken til en historiker. Haave har gjort et usedvanlig grundig kildearbeid, og resultatet er både nyansert og rikt på perspektiver. Gjennomgående trekker Haave linjer mellom ideologi og praksis på Sanderud og de samtidige nasjonale og internasjonale holdninger. Sanderud sykehus blir slik like mye et eksempel på bredere nasjonale og internasjonale praksiser i psykiatrien som et studieobjekt i seg selv. I motsetning til det meste annet som foreligger i denne sjangeren (jubileumsverk for institusjoner) vil Ambisjon og handling derfor bli lest og opplevd som relevant av langt flere enn dem som har hatt et forhold til Sanderud sykehus.

\section{Omfattende behandlingsforsøk}

Psykiatriens terapeutiske arsenal i mellomkrigstiden var omfattende. Julius WagnerJauregg (1857-1940) introduserte malaria- behandling av paralytiske syfilitikere og mottok nobelprisen i 1927. Egas Moniz (1874-1955) ble tildelt prisen i 1949 for innføringen av lobotomi. Det meste av dette er kjent, men hvor mange har i dag hørt om defokalisering, insulinsjokk, cardiazolterapi eller sovekur? De var alle viktige deler av psykiaterens terapeutiske arsenal fra mellomkrigstiden og utover, noen så langt som til 1960-årene. Gjennom store deler av det tidlige 1900-tallet, før psykofarmakaens inntreden i 1950-årene, var psykiatrien preget av en stor behandlingsiver.

Insulinsjokkterapien ble først prøvd ut i Wien, der Manfred Sakel (1900-57) hadde brukt insulin på morfinavhengige. Noen ganger gikk behandlingen galt og pasientene gled inn i et hypoglykemisk koma. Sakel fant ut at mentalt forstyrrede pasienter ble rolige etter dette og begynte å prøve det ut på schizofrene. Metoden besto i gjentatte injeksjoner med høye doser insulin - i den hensikt å produsere koma. Haave dokumenterer at den største enkeltdosen gitt til en pasient på Sanderud var 440 IE. Behandlingen pågikk gjennom mange uker. Det er nesten ikke mulig å forestille seg hvilken enorm påkjenning dette har vært for pasienten.

Det er i ettertid såre enkelt å sette seg på

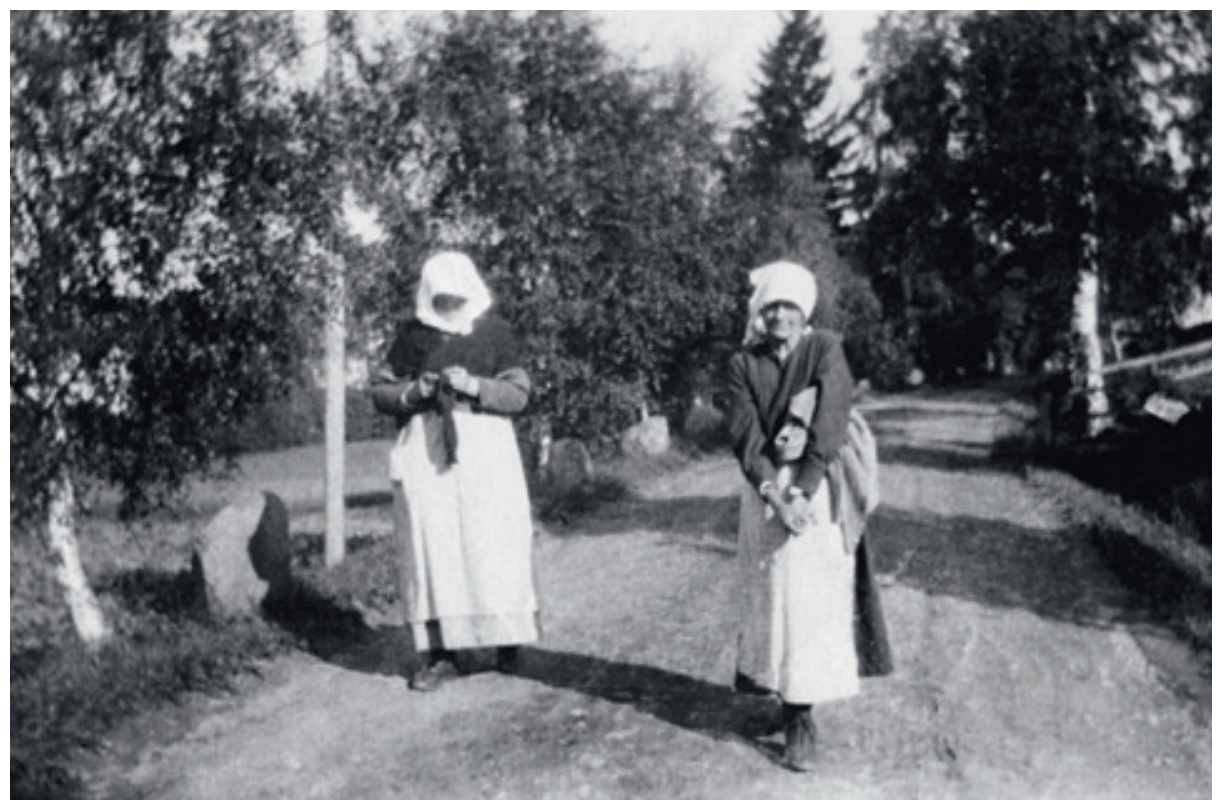

Et vesentlig prinsipp var at pasientene i de åpne avdelingene - kolonipasientene - skulle sysselsettes så mye som mulig. Dette er to kvinner som bodde på Blårud, som var kvinnekoloni fra 1908 til 1934. Den ene har strikketøyet med seg. Bildet er tatt før 1920. Fotografiet tilhører Per Haave 


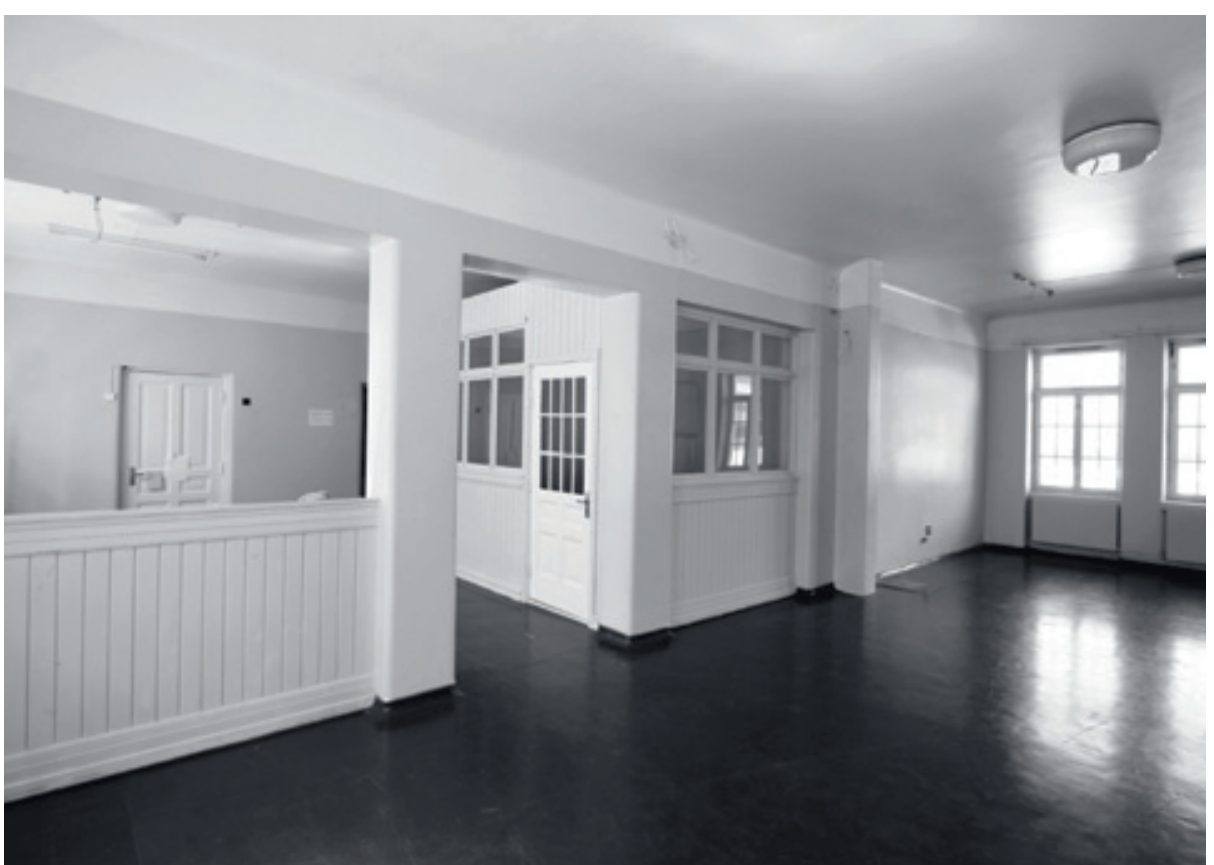

Vaktsalen med vaktrommet $i$ avdeling III for «rolige kvinner». Bak den lave veggen til venstre lå den såkalte insulinstua, der pasientene ble lagt $i$ «insulinsjokk». Foto Vegard Haave

sin høye hest og moralisere over dette materialet. Som Haave påpeker visste man fra begynnelsen av at metoden var farlig og kunne ta liv. Fra tidlig i 1950-årene begynte kritiske røster å gjøre seg langt mer gjeldende. Til tross for det ble den siste insulinsjokkbehandlingen ved Sanderud gitt så sent som i 1960-årene. Haaves beskrivelse er imidlertid preget av at han ikke går inn i materialet først og fremst for å dømme, men for å forstå. Gjennom detaljerte beskrivelser viser han hvordan behandlingen var ressurskrevende. Den krevde et eget rom, og legene måtte være kontinuerlig til stede under en prosedyre som, i tillegg til å produsere mye illeluktende kroppsvæsker, tok mye av deres tid. Det ville vært langt enklere måter for legene å få tilfredsstilt et maktbehov på i en tid der lege-pasient-forholdet var ekstremt patriarkalsk og maktforskjellen var påfallende. Men dette handlet også om det konstante overbelegget på de psykiatriske institusjonene, «asylnøden», og psykiaternes ønske om å gjøre noe også for disse pasientene $\mathrm{i}$ en tid da medisinen for øvrig var blitt stadig mer terapeutisk aktiv. Det Haave tydelig viser i sitt lavmælte språk, er at konsekvensene uansett var forferdelige.

Haaves styrke er først og fremst grundig arkivarbeid, med svært god teft i utvelgingen av det empiriske materialet. Arkivarbeidet skiller den fra f.eks. Einar Kringlens bok om norsk psykiatrihistorie fra 2007 (2). Dette gjelder spesielt for perioden mellom de to krigene, der Haave ikke bare konsentrerer seg om behandlingspraksis og hverdag i hospitalet, men også løfter frem pleiepersonellets arbeidstid og utdanningsnivå. For perioden etter 1950 er det åpenbart at han har hatt litt dårligere tid - jubi- leumsboken skulle være ferdig til 2008. Noen annen forklaring er det vanskelig å finne på at nærlesningsstrategien, vektleggingen av praksis i institusjonen, blir borte til fordel for et mer tradisjonelt institusjonshistorisk og forvaltningshistorisk perspektiv, som blir vesentlig tørrere å lese. Misforstå meg rett: Overgangen fra tradisjonelt asyl til spesialisert behandlingssykehus er tidligere blitt stemoderlig behandlet, og er viktig. Men dette skiftet av perspektiv fører til at introduksjonen av psykofarmaka ikke får like mye oppmerksomhet som beskrivelsen av prosedyrene foran.

\section{Manglende perspektiver}

Haave hevder at det gjennom hele 1900tallet går en uavbrutt linje fra da forestillingen om «den syke hjernen» etableres rundt 1900. Først ble utvendige behandlingsformer som sengeleie og hydroterapi benyttet. Dernest kom sjokkbehandlingen, som skulle virke inne i selve kroppen ved å påvirke hjernen enten medikamentelt (insulin eller cardiazol) eller elektrisk (elektrosjokk). Med lobotomi utsatte man hjernen for direkte inngrep, og med psykofarmaka kunne man påvirke hjernen på molekylærnivå. Hvorfor er han da ikke like grundig når det gjelder introduksjonen av psykofarmaka, vår tids behandling av den syke hjernen, som han tar for seg de første behandlingsmetodene? Det virker langt på vei som om han har tatt psykofarmaka for gitt, siden introduksjonen av de nye medikamentene blir gjenstand for en langt mindre historiserende undersøkelse enn de andre behandlingsformene. Vi får vite for lite om hvordan ble de brukt, på hvem og ikke minst - hvilken effekt de hadde på den psykiatriske tenkemåte. Flere forskere har i den senere tid påpekt hvordan den medikamentelle revolusjon i 1950-årene endret måten man tenkte om sykdom på - hypertensjon ble noe helt annet etter introduksjonen av antihypertensivene (3) og psykisk sykdom ble drastisk endret etter introduksjonen av psykofarmaka (4). I de siste femti år har den farmasøytiske industri gjort et stadig sterkere inntog på den psykiatriske arena, en massiv pengemaskin som er avhengig av en bestemt måte å se psykisk sykdom på. Med de selektive serotoninreopptakshemmerne har denne biologiske psykiatrien også satt dype spor i kulturen generelt og endret måten vi erfarer og forstår oss selv på. Per Haave kunne levert et viktig innspill til vår samtid ved å ofre flere sider på tilblivelsen av denne æraen, med utgangspunkt i det rike kildematerialet han sitter på. Jeg håper han griper denne muligheten ved en senere anledning.

Det er for øvrig et perspektiv denne anmelder savner i hele denne utgivelsen: Selv for den tidlige fasen, der Haave fint viser hvordan nye behandlingsmåter introduseres og bakgrunnen for dem i nye tenkemåter i medisinen, er han ikke opptatt av hvordan de nye behandlingsformene virker tilbake på psykiatriens selvforståelse. Med andre ord: Hvordan virker ny praksis inn på etablerte forståelsesmåter?

\section{Avslutning}

Til tross for disse innvendingene: Dette er et velskrevet, originalt og informasjonsrikt bidrag til norsk medisinsk historie, og det fortjener en stor leserskare. Illustrasjonene er fotografier fra Sanderuds arkiv, som i seg selv er sterke vitnesbyrd. Hvis vi kan lære av historien - og det tror vi vel alle at vi kan på et eller annet plan - så burde den også stå på pensumlisten til alle fremtidige leger. Læringspunkt nummer 1 for legelesere: Gode intensjoner er ikke noen garanti for god praksis. Det viser denne historien med all mulig tydelighet.

\section{Anne Kveim Lie}

Institutt for allmenn- og samfunnsmedisin Universitetet i Oslo

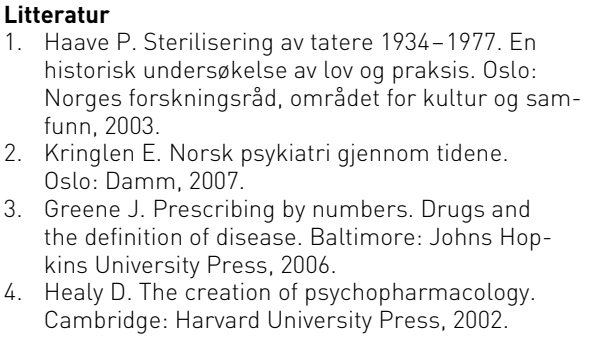

2. Kringlen E. Norsk psykiatri gjennom tidene. Oslo: Damm, 2007

3. Greene J. Prescribing by numbers. Drugs and the definition of disease. Baltimore: Johns Hopkins University Press, 2006.

4. Healy D. The creation of psychopharmacology. Cambridge: Harvard University Press, 2002. 